ZOOLOGIA 27 (5): 795-802, October, 2010

doi: $10.1590 /$ S1984-46702010000500016

\title{
A new Scinax of the S. catharinae species group from Central Brazil (Amphibia: Anura: Hylidae)
}

\author{
José P. Pombal Jr; Ronald R. Carvalho Jr²; Marco Antônio S. Canelas ${ }^{3}$ \& Rogério P. Bastos ${ }^{4}$ \\ ${ }^{1}$ Departamento de Vertebrados, Museu Nacional, Universidade Federal do Rio de Janeiro. Quinta da Boa Vista, \\ 20940-040 Rio de Janeiro, RJ, Brazil. E-mail: pombal@acd.ufri.br \\ ${ }^{2}$ Táxon Meio Ambiente - Estudos e Projetos. Rua Marco Aurélio de Miranda 406/903, Buritis, 30575-210 Belo Horizonte, \\ MG, Brazil. E-mail: rcjunior.bh@terra.com.br \\ ${ }^{3}$ Herpeto Consultoria Ambiental. Rua Caraça 539, Serra, 30220-260 Belo Horizonte, MG, Brazil. \\ E-mail: marcocanellas@hotmail.com \\ ${ }^{4}$ Departamento de Ecologia, Instituto de Ciências Biológicas, Universidade Federal de Goiás. Caixa Postal 131, \\ 74001-970 Goiânia, GO, Brazil. E-mail: rogerio@persogo.com.br
}

\begin{abstract}
A new species of Scinax Wagler, 1830 belonging to the $S$. catharinae species group is described from the state of Goiás, in the Cerrado Biome, Brazil. Scinax skaios sp. nov. is characterized by short snout-vent length (males ranging 23.2-29.6 mm; females 30.7-36.1 mm), snout subovoid in dorsal view and protruding in lateral view; no tubercle on canthus rostralis; an inverted triangular interorbital blotch; no externally expanded vocal sac; dorsal skin texture moderately rugose; absence of a thick externally well differentiated inguinal gland; hidden areas of the thigh with vermiculate color pattern. The descriptions of the vocalizations are provided.
\end{abstract}

KEY WORDS. Amphibians; Cerrado; Dendropsophini; new species; Scinax skaios sp. nov.; vocalization.

Scinax Wagler, 1830 is the largest genus of Hylinae with about 90 species occurring from eastern and southern Mexico to Argentina and Uruguay, Trinidad and Tobago, and St. Lucia Island (Frost 2010). New species are frequently described (e.g. Pugliese et al. 2004, 2009, Lima et al. 2005, Brasileiro et al. 2007, Drummond et al. 2007). FaIVovich et al. (2005) based on molecular characters and some morphological features recognized two clades: the $S$. catharinae clade and the $S$. ruber clade. Within the $S$. catharinae clade, they recognized the $S$. catharinae and the $S$. perpusillus species groups. As currently recognized, the $S$. catharinae species group is the largest in the genus, comprising 28 species distributed in eastern and central Brazil, northeastern Argentina, southern Paraguay, and Uruguay (Frost 2010). Most species are found in the Atlantic Rainforest Domain (sensu Aв'SÁBER 1977) and are typically forest dwellers. The species presently allocated to this species group are $S$. agilis (Cruz \& Peixoto, 1983), S. albicans (Bokermann, 1967), S. angrensis (B. Lutz, 1973), S. argyreornatus (Miranda-Ribeiro, 1926), S. ariadne (Bokermann, 1967), S. aromothyella Faivovich, 2005, S. berthae (Barrio, 1962), S. brieni (De Witte, 1930), S. canastrensis (Cardoso \& Haddad, 1982), S. carnevallii (Caramaschi \& Kisteumacher, 1989), S. catharinae (Boulenger, 1888), S. centralis Pombal \& Bastos, 1996, S. flavoguttatus (A. Lutz \& B. Lutz, 1939), S. heyeri (Peixoto \& Weygoldt in Weygoldt, 1986), S. hiemalis (Haddad \& Pombal, 1987), S. humilis (B. Lutz, 1954), S. jureia (Pombal \& Gordo, 1991), S. kautskyi (Carvalho-e-Silva \& Peixoto, 1991), S. littoralis (Pombal \& Gordo, 1991), S. longilineus (B. Lutz, 1968), S. luizotavioi (Caramaschi \& Kisteumacher, 1989), S. machadoi (Bokermann \& Sazima, 1973), S. obtriangulatus (B. Lutz, 1973), S. ranki (Andrade \& Cardoso, 1987), S. rizibilis (Bokermann, 1964), S. strigilatus (Spix, 1824), S. trapicheiroi (B. Lutz, 1954), and S. tripui Lourenço, Nascimento \& Pires, 2009.

During field work in central Brazil in 2005, we (RRC and MASC) collected specimens of the Scinax catharinae species group at Santa Rita do Novo Destino, state of Goiás, Central Brazil. These are different from all other recognized taxa in the species group and are described herein. This new species and $S$. centralis are the most inland taxa found in gallery forest from Cerrado Domain, in Brazil (see Pombal \& Bastos 1996).

\section{MATERIAL AND METHODS}

Specimens used in the description or examined for comparisons are deposited in theAdolpho Lutz Collection (AL-MN, housed in Museu Nacional, Rio de Janeiro, Brazil), Museu de Ciências Naturais da PUC Minas (MCNAM, Belo Horizonte, Minas Gerais, Brazil), and Museu Nacional (MNRJ, Rio de Janeiro, Brazil).

The following measurements were taken with calipers: SVL (snout-vent length), HW (head width), HL (head length), THL (thigh length), TBL (tibia length), and FL (foot length). 
Six others variables, ED (eye diameter), IOD (interorbital distance), IND (internarial distance), END (eye-nostril distance), NSD (nostril-snout distance), and TD (tympanum diameter), were measured using an ocular micrometer in a Zeiss stereomicroscope. All measurements are in millimeters and followed Duellman (2001) and Cei (1980). Webbing formula notation follows Savage \& Heyer (1967), as modified by Myers \& Duellman (1982). The sex was determined by smaller size and forearm more robust in males and in females was made a small lateral incision on abdomen to visualize the egg mass.

Vocalizations of two males were recorded with a Panasonic RQ-L309 portable tape recorder. The vocalizations were edited at a sampling frequency of $22 \mathrm{kHz}$ and 16 bits resolution with a PC-Pentium computer and analyzed with Avisoft-Sonagraph Light and Cool Edit 96 software. The oscilogram and sonogram was produced with 256 points, 50\% overlap, and in flat top.

\section{TAXONOMY}

\section{Scinax skaios sp. nov.}

Figs 1-6

Holotype. MNRJ 54471, female, collected at Anglo American do Brasil (15 $05^{\prime} 17^{\prime \prime}$ S, $\left.49^{\circ} 02^{\prime} 23^{\prime \prime} \mathrm{W}\right)$, municipality of Santa Rita do Novo Destino, state of Goiás, Brazil, 28.VI.2005, Ronald R. Carvalho Jr \& Marco Antônio S. Canelas leg. Paratopotypes. MCNAM 6220-6221 (one female and one male), 22.VI.2005; MCNAM 6222-6223 (one male and one female), 28.VI.2005; MCNAM 6225 (one female), 28.VI.2005; MCNAM 6227 (one female), 28.VI.2005; MCNAM 6229-31 (three males), 28.VI.2005; MCNAM 6233 (one female), 28.VI.2005; MNRJ 54472-74 (one male and two females), 28.VI.2005. All collected at the type locality by the same collectors.

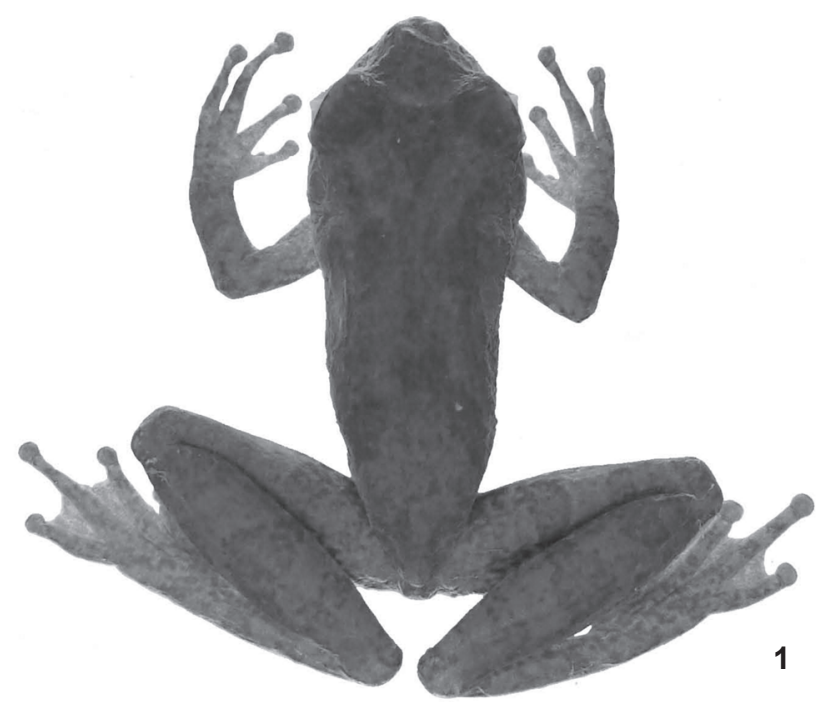

Diagnosis. A small species (SVL of males 23.2-27.6 mm and females $29.7-36.1 \mathrm{~mm}$ ) belonging to the Scinax catharinae species group, characterized by snout subovoid in dorsal view and protruding in lateral view; no tubercle on the canthus rostralis; an inverted triangular interorbital blotch; no vocal sac expanded externally; dorsal skin texture moderately rugose; absence of a thick externally well differentiated inguinal gland; hidden areas of thigh with vermiculate pattern.

Comparison with other species. Scinax skaios can be separated from $S$. agilis, S. argyreornatus, $S$. berthae, S. centralis, and $S$. machadoi by the greater male SVL (male combined SVL 13.5$22.2 \mathrm{~mm}$ in those species; Bokermann \& Sazima 1973, Cruz \& Peixoto 1983, Рombal \& Bastos 1996, Faivovich 2005). By contrast, can be distinguished from $S$. ariadne and $S$. catharinae by the smaller male SVL (male combined SVL 33.0-36.5; B. LuTZ 1973, where $S$. ariadne was called Hyla catharinae bocainensis). It can be separated from S. albicans, S. flavoguttatus, S. longilineus, and $S$. strigilatus by the smaller female (female combined SVL 36.9-43.1; B. Lutz 1973, where S. albicans was called of Hyla catharinae opalina; ANdRAde \& CARdoso 1990, Pimenta et al. 2007). Scinax skaios further differs from S. longilineus by the less rugose dorsal skin, (moderately rugose in $S$. skaios). The lack of thick, externally well differentiated inguinal glands distinguishes $S$. skaios from S. centralis and S. hiemalis (POMBAL \& BASTOS 1996, HADDAD \& Pombal 1987). The slightly visible and inverted triangular interocular blotch differentiates the new species from $S$. angrensis, S. flavoguttatus, S. heyeri, S. humilis, S. kaustkyi, S. littoralis, and $S$. tripui (in these species the interocular blotch is W-shaped, sometimes interrupted; (B. Lutz 1973, Регхото \& Weygodt 1987, Caramaschi \& Kisteumacher 1989, Carvalho e Silva \& Peixoto 1991, Pombal \& Gordo 1991, Lourenço et al. 2009) and from S. trapicheiroi, in which the interocular blotch is very large,

Figures 1-2. Scinax skaios sp. nov., holotype, MNRJ 54471, female SVL 29.6 mm, in dorsal (1) and ventral (2) views. 

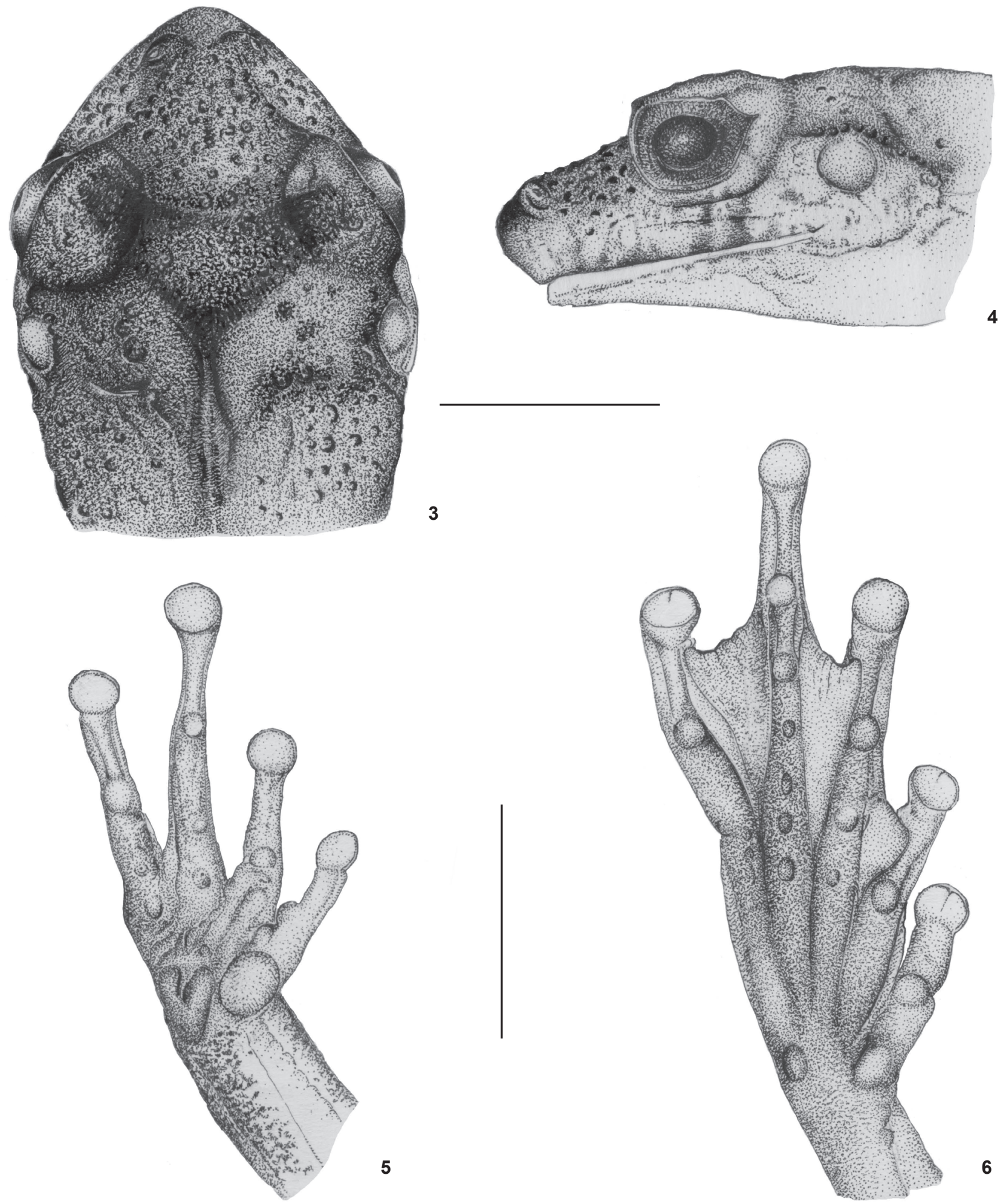

3

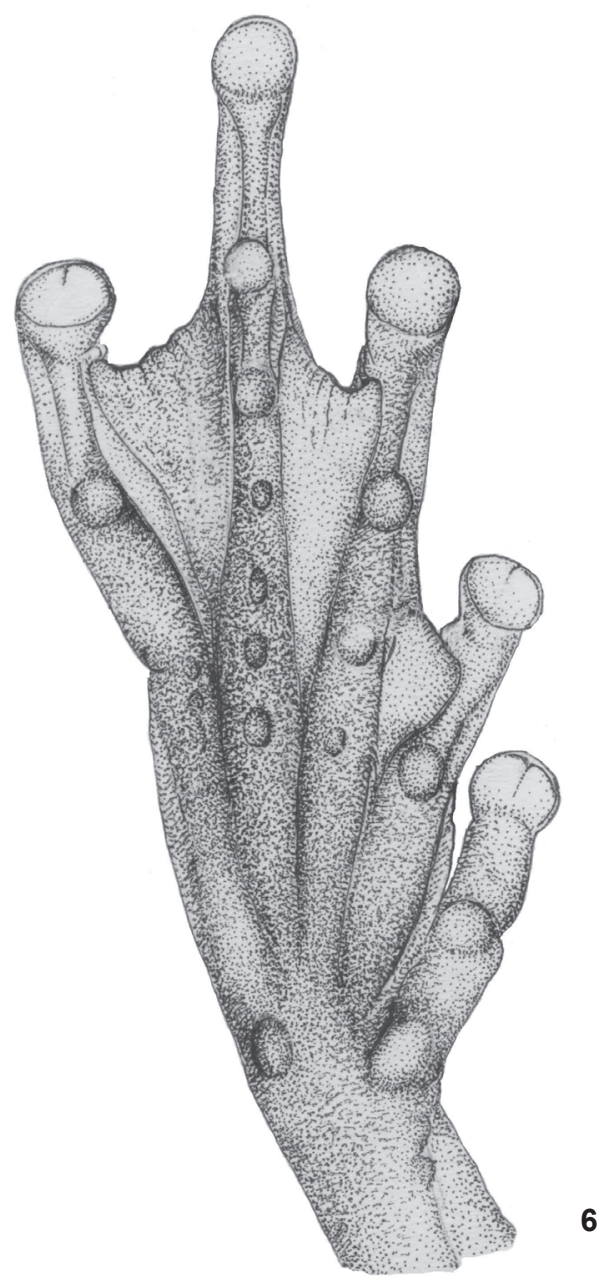

Figures 3-6. Scinax skaios sp. nov., holotype (MNRJ 54471): dorsal (3) and lateral (4) views of head; ventral views of hand (5) and foot (6). Scale $=5 \mathrm{~mm}$. 
extending well onto to the scapular region (B. LuTz 1973). Further, S. skaios differs from S. flavoguttaus and S. heyeri by lacking vivid orange color on the hidden surfaces of the thigh (B. Lutz 1973, Peixoto \& Weygoldt 1987). The lack of an externally distended vocal sac distinguishes $S$. aromothyella from the new species (Faivovich 2005). The absence of an enlarged nuptial pad distinguishes $S$. skaios from $S$. rizibilis. Even though the male SVL of S. skaios and S. luizotavioi - males 21.8-24.3 mm SVL (Caramaschi \& Kisteumacher 1989) sometimes overlap, S. skaios can be generally recognized y its larger size, less acuminate snout in dorsal view, skin of dorsum more rugose (smooth with tubercles scattered on the dorsum in S. luizotavioi), and vocal sac not expanded (lateral and slightly expanded in S. luizotavioi). The male SVL of $S$. skaios also overlaps with that of S. carnevallii - males 21.0-25.0 mm SVL (CARamaschi \& Kisteumacher 1989). The former can be separated from the latter by generally being larger, having a more robust body, a less acuminate snout in lateral view, and by lacking two oblique white lines from the eye to the upper lip. From $S$. jureia, $S$. skaios differs by having a rugose dorsum (smooth in $S$. jureia) and a less developed supratympanic fold. The lack of a contrasting dorsal color pattern with light line drawing distinguishes the new species from $S$. canastrensis. From S. ranki, the new species can be distinguished by being larger, some overlapping occurs in $S$. ranki male SVL 20.2-24.8 mm (ANDRADE \& CARDOSO 1987), and by the more rugose dorsal skin (smooth with tubercles scattered on dorsum in $S$. ranki), and vocal sac not expanded - lateral and slightly expanded in S. ranki (ANDRADE \& CARDOSO 1987). Scinax skaios differs from $S$. obtriangulatus by the less rounded head in dorsal view, the rugose skin, the medium-sized finger and toe discs (large in $S$. obtriangulatus) and the less conspicuous dorsolateral stripes (very conspicuous in S. obtriangulatus). The new species differs from $S$. brieni by smaller interocular blotch, small finger and toe discs (large in S. brieni); absence of a tubercle between eye-nostril (present in S. brieni), and smaller males - SVL of males 30.5-32.7 $\mathrm{mm}$ in S. brieni (Heyer et al. 1990). Further, the new species can be distinguished from all species of the $S$. catharinae group, except by $S$. longilineus, by the vermiculate color pattern in hidden areas of the thigh.

Description of the holotype. Body moderately slender; head slightly longer than wider and slightly wider than body; snout subovoid in dorsal view, protruding in lateral view; nostril protuberant, located laterally, immediately posterior to tip of snout; canthus rostralis well marked, nearly concave; loreal region concave; no tubercle on canthus rostralis; eyes protuberant, large; tympanum distinct, small round, larger than diameter of finger III disc; supratympanic fold well defined evident, extending from posterior corner of eye to just anterior to shoulder; tongue large, oval, free laterally and posteriorly, slightly notched behind; two transverse series of four vomerine teeth between the large elliptical choanae. Arms slender; forearms more robust than upper arms; fingers narrow; finger lengths $\mathrm{I}<\mathrm{II}<\mathrm{IV}<\mathrm{III}$; subarticular tubercles nearly conical; few small supernumerary tubercles; outer metacarpal tubercle large and bifid; inner metacarpal tubercle large, nearly ovoid; finger discs medium-sized, nearly round; disc of finger I smaller than others; webbing between fingers absent. Legs slender, tibia longer than thigh; sum of thigh and tibia lengths greater than SVL; toes slender; toe length $\mathrm{I}<\mathrm{II}<\mathrm{III} \simeq \mathrm{V}<\mathrm{IV}$; subarticular tubercles round, protruding; outer metatarsal tubercle round, small; inner metatarsal tubercle small, nearly elliptical; toe discs medium-sized, approximately round; small supernumerary tubercles present; webbing formula I2-2II1-3-III1-2-IV2-1V. Pectoral fold absent; dorsal surfaces and flanks weakly rugose with scattered granules, mainly in sacral region and head where they are larger; gular region and chest finely granular; belly and ventral surfaces of thighs aureolate; inguinal glands not visible.

Color in life. Dorsum color ranged from beige or pale green to brown or dark brow, with irregular black spots; granules on dorsum brown, yellow, or orange; tympanum bronze; inverted triangular interorbital blotch dark brown, bordered by a narrow yellow line. Upper surfaces of arms and legs brown with irregular dark brown stripes. Hidden areas of thighs brown or pale green with vermiculate dark brown; belly white to light brown; throat whitish with brown dots; iris pale to dull bronze with black median vertical streaks (Fig. 7).

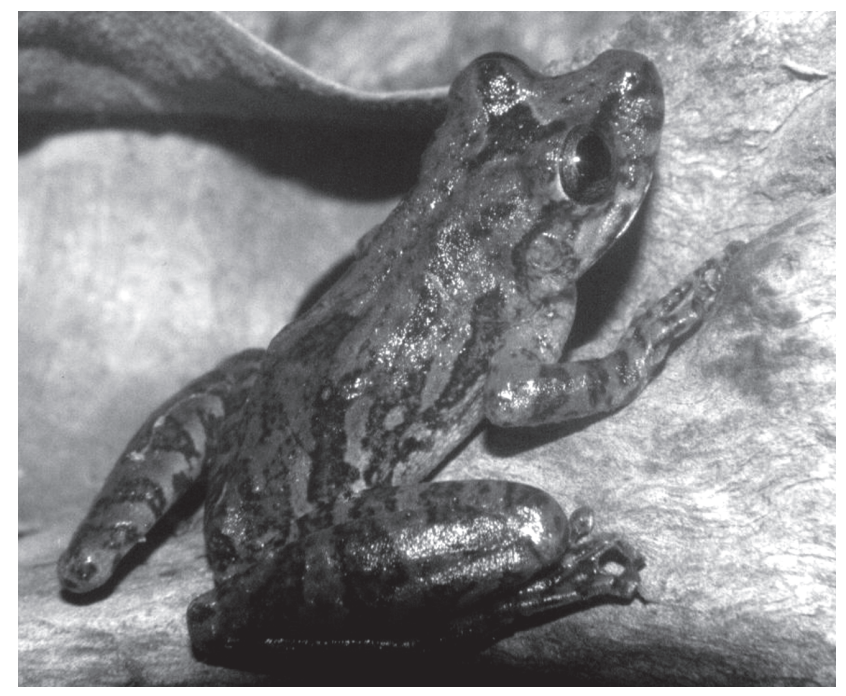

Figure 7. Adult female in life of S. skaios sp. nov. (MCNAM 6220) from the type-locality at municipality of Santa Rita do Novo Destino, state of Goiás, Brazil. Photo by RRC.

Color in preservative (70\% alcohol). Color similar to those in life, but darker.

Variation. Measurements are in table I. The females are larger than males. The forearm is slightly more robust in males (width/forearm length 0.37-0.43 in females and 0.45-0.54 in males). The dorsum may be brown or dark brown. Skin on dor- 
Table I. Measurements (mm) of holotype (MNRJ 54474) and paratypes of S. skaios sp. nov. (M) male and (F) female.

\begin{tabular}{|c|c|c|c|c|c|c|c|c|c|c|c|c|c|}
\hline Individual & Sex & SVL & $\mathrm{HL}$ & $\mathrm{HW}$ & ED & TD & IOD & IND & END & NSD & THL & TBL & $\mathrm{FL}$ \\
\hline MCNAM 6221 & $M$ & 27.0 & 10.6 & 9.5 & 3.3 & 1.2 & 2.9 & 2.0 & 2.6 & 1.0 & 14.5 & 16.1 & 13.0 \\
\hline MCNAM 6222 & $M$ & 26.0 & 10.2 & 9.2 & 3.5 & 1.2 & 3.0 & 2.2 & 2.3 & 1.1 & 12.5 & 14.1 & 11.6 \\
\hline MCNAM 6227 & $M$ & 23.2 & 9.4 & 8.0 & 2.9 & 1.5 & 2.5 & 1.9 & 2.0 & 1.5 & 12.4 & 14.0 & 10.7 \\
\hline MCNAM 6229 & $M$ & 25.2 & 9.6 & 9.0 & 3.2 & 1.3 & 3.0 & 2.0 & 2.3 & 1.1 & 12.4 & 15.7 & 11.7 \\
\hline MCNAM 6230 & $M$ & 25.9 & 9.9 & 8.8 & 3.2 & 1.5 & 3.0 & 2.0 & 2.3 & 1.1 & 14.5 & 15.3 & 12.1 \\
\hline MCNAM 6231 & $M$ & 26.7 & 10.1 & 9.1 & 3.2 & 1.3 & 2.8 & 2.3 & 2.4 & 1.0 & 13.3 & 15.7 & 12.6 \\
\hline MNRJ 54473 & $M$ & 25.1 & 10.0 & 8.5 & 3.1 & 1.4 & 2.7 & 2.2 & 2.1 & 1.1 & 12.7 & 14.6 & 11.5 \\
\hline MNRJ 54474 & $M$ & 25.1 & 9.7 & 8.8 & 3.2 & 1.1 & 3.1 & 2.2 & 2.1 & 1.1 & 13.0 & 15.0 & 11.4 \\
\hline MNRJ 54471 & $\mathrm{~F}$ & 29.7 & 11.4 & 11.0 & 3.2 & 1.6 & 2.8 & 2.0 & 2.3 & 0.5 & 16.0 & 18.1 & 13.7 \\
\hline MCNAM 6220 & $\mathrm{~F}$ & 33.9 & 12.2 & 10.5 & 3.2 & 1.6 & 3.1 & 2.5 & 3.0 & 1.2 & 16.3 & 19.1 & 14.7 \\
\hline MCNAM 6223 & $\mathrm{~F}$ & 36.1 & 13.6 & 12.9 & 4.0 & 2.0 & 3.7 & 3.0 & 3.0 & 1.9 & 18.3 & 20.3 & 15.6 \\
\hline MCNAM 6225 & $\mathrm{~F}$ & 31.5 & 11.8 & 10.7 & 3.5 & 1.6 & 3.2 & 2.4 & 3.2 & 1.2 & 16.2 & 18.4 & 13.7 \\
\hline MCNAM 6233 & $\mathrm{~F}$ & 30.7 & 11.2 & 10.2 & 3.6 & 1.1 & 3.2 & 2.8 & 2.9 & 1.3 & 16.9 & 18.3 & 12.5 \\
\hline MNRJ 54472 & $\mathrm{~F}$ & 31.2 & 11.8 & 10.9 & 3.4 & 1.6 & 3.4 & 2.6 & 2.9 & 1.2 & 15.9 & 18.4 & 14.2 \\
\hline
\end{tabular}

sum varied from smooth to tuberculate. About $75 \%$ of specimens (males and females) have a clear line between eyes. Supernumerary tubercles vary in number.

Vocalizations. Two types of vocalizations (Figs 8-11) were recorded: a long call (here considered the advertisement call because it was more frequent) and a short call (named isolated call). Two advertisement calls were recorded from two males. The duration of the two advertisement calls was $4.42 \mathrm{~s}$ and 7.9 s, which presented 42 and 73 notes. Average note duration was $0.27 \pm 0.012 \mathrm{~s}(0.013-0.056, \mathrm{~N}=10$ notes $)$, emitted on an interval of $0.087 \pm 0.053 \mathrm{~s}(0.036-0.168 \mathrm{~s}, \mathrm{~N}=10$ intervals $)$. The calls presented 312 or 612 pulses and notes had $9.2 \pm 3.33$ pulses (5-16, $\mathrm{N}=10$ notes). The dominant frequencies were 2.205 and $2.243 \mathrm{~Hz}$.

Three isolated calls were recorded from two males and showed pulsed structure with duration of $0.036 \pm 0.017 \mathrm{~s}(0.017$ $0.049 \mathrm{~s}, \mathrm{~N}=3$ calls) and $14.43 \pm 5,69$ pulses (8-19 pulses, $\mathrm{n}=3$ calls). The dominant frequency varied from 2.310 to $2.348 \mathrm{~Hz}$ $(\mathrm{X}=2,323 \pm 52 \mathrm{~Hz})$. Vocalizations of the following species of the Scinax catharinae group are described: S. albicans (HEYER 1980), $S$. argyreornatus (BoKERMANN 1966, POMBAL et al. 1995), S. canastrensis (CARDoso \& Haddad 1982), S. catharinae (HeYER 1980), S. centralis (Pombal \& Bastos 1996), S. hiemalis (Haddad \& Pombal 1987), S. machadoi (Bokermann \& SAZIMA 1973), S. ranki (Andrade \& Cardoso 1987), S. rizibilis (BoKermann 1964, POMBal et al. 1995, Bastos \& HADDAD 2002). Vocalizations of species this group are complex (Pombal et al. 1995, Pombal \& Bastos 1996). Given that the available descriptions are based on different equipments and the acoustic parameters differ between studies (see POMBAL et al. 1995 for revision) we have avoided a detailed comparison among these vocalizations. With one exception (see below), the advertisement call of Scinax skaios differs from all calls described so far by having more notes per call. The advertisement call of $S$. argyreornatus shares this feature, but it can be distinguished by its lower dominant frequency (Pombal et al. 1995).

Habitat and natural history. The Cerrado Biome covers about 2 million $\mathrm{km}^{2}$, representing $22 \%$ of Brazil, plus small areas in eastern Bolivia and northwestern Paraguay. It extends from the southern borders of the Amazonian forest to areas in the southern states of São Paulo and Paraná. The distribution of the Cerrado is coincident with the plateau of central Brazil. Narrow forest strips are called "gallery forest" because the crowns of the trees form a gallery over the water of small rivers or rivulets. The central Brazilian riverine forests represent floristic intrusions of the Amazonian and/or Atlantic forest into the Cerrado Domain (Oliveira-Filho \& RatTER 2002). Scinax skaios is the second species of the $S$. catharinae species group recorded only in the Cerrado biome (Pombal \& Bastos 1996). Like $S$. centralis, $S$. skaios is encountered in gallery forests.

Males vocalized close to the rivulets in the gallery forests or in the cerrado near gallery forests. As vocalization site, the males utilized branches of marginal vegetation, rocks or ground (0-1.0 $\mathrm{m}$ above the water). The vocalizations could be heard staring around 21:00 $\mathrm{h}$. The amplexus is axilar.

Distribution. The new species is known only from the type locality in the municipality of Santa Rita do Novo Destino, state of Goiás, Brazil.

Etymology. Skaios is a Greek word meaning western. Most of the species of the Scinax catharinae species group occur in the Atlantic Forest in eastern Brazil (POMBAL \& BASTos 1996). 


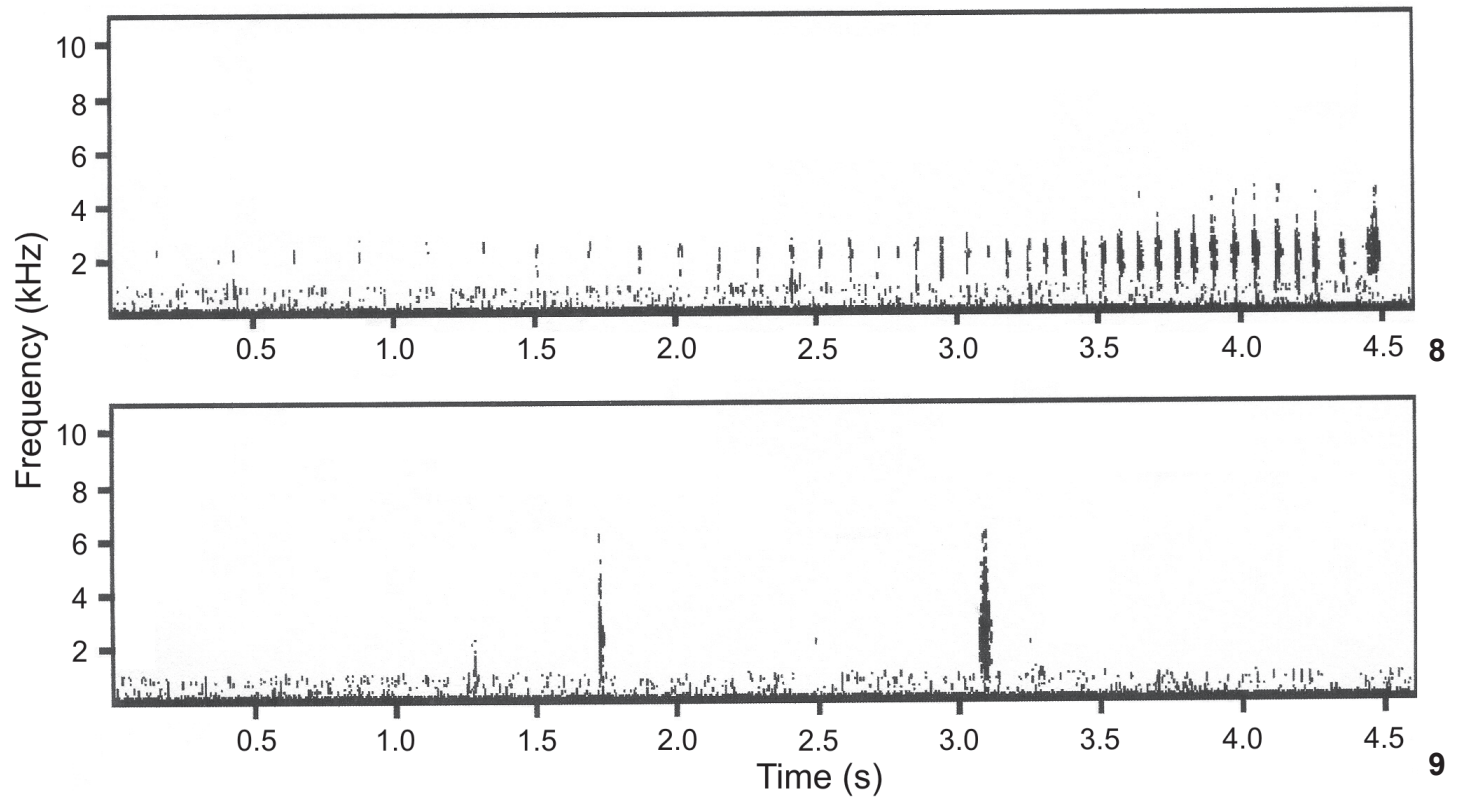

Figures 8-9. Spectrogram of the advertisement call and isolated call of S. skaios sp. nov. (MCNAM 6221) from type locality at municipality of Santa Rita do Novo Destino, state of Goiás, Brazil, recorded on 22 June 2005. Air temperature $23.5^{\circ} \mathrm{C}$.

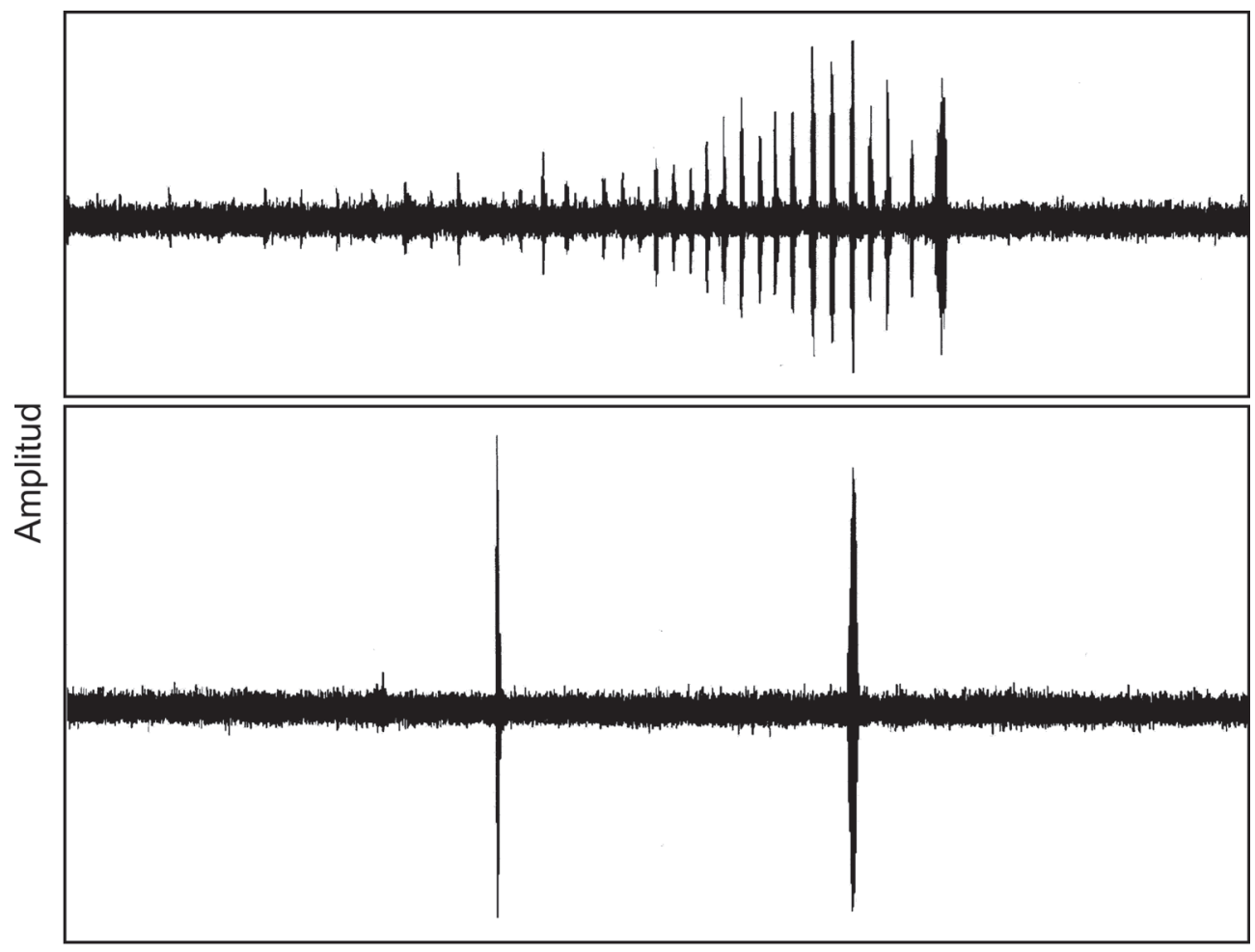

Time (s)

Figures 10-11. Waveform of the advertisement call and isolated call of S. skaios sp. nov. (MCNAM 6221) from type locality at municipality of Santa Rita do Novo Destino, state of Goiás, Brazil, recorded on 22 June 2005 . Air temperature $23.5^{\circ} \mathrm{C}$. The time is $4.5 \mathrm{~s}$. 


\section{ACKNOWLEDGEMENTS}

We thank D.S. Fernandes, A.C.C. Lourenço, and M.W. Cardoso for helpful suggestions on the manuscript; P.R. Nascimento for the line drawings; D. Baêta and A.C.C. Lourenço for the pictures 1 and 2. We thank Anglo American do Brasil for the license to access the study area and for financial support. The Instituto Brasileiro do Meio Ambiente e dos Recursos Naturais Renováveis/Centro de Conservação e Manejo de Répteis e Anfíbios (Ibama/RAN) provided capture/transportation license 079/2005-CGFAU/LIC. The Conselho Nacional de Desenvolvimento Científico e Tecnológico (CNPq) provided fellowships to JPP and RPB. Financial supports were provided by ANPCy PICT 2007/2202, CNPq, Funape/UFG, Fundação Carlos Chagas Filho de Amparo à Pesquisa do Estado do Rio de Janeiro (FAPERJ), and CNPq.

\section{LITERATURE CITED}

Aв'SABER, A.N. 1977.Os domínios morfoclimáticos na América do Sul: primeira aproximação. Geomorfologia 52: 1-23.

Andrade, G.V. \& A.J. Cardoso. 1987. Reconhecimento do grupo rizibilis: descrição de uma nova espécie de Hyla (Amphibia, Anura). Revista Brasileira de Zoologia 3 (7): 433-440.

Andrade, G.V. \& A.J. Cardoso. 1990. Descrição de larvas e biologia de quatro espécies de Hyla (Amphibia, Anura). Revista Brasileira de Biologia 51 (2): 391-402.

Bastos, R.P. \& C.F.B. Haddad. 2002. Acoustic and aggressive interactions in Scinax rizibilis (Anura: Hylidae) during the reproductive acticity in southeastern Brazil. AmphibiaReptilia 23: 97-104.

Bokermann, W.C.A. 1964. Uma nova espécie de Hyla da Serra do Mar em São Paulo (Amphibia, Salientia). Revista Brasileira de Biologia 24 (4): 429-434.

Bokermann, W.C.A. 1966. Notas sobre Hylidae do Espírito Santo (Amphibia, Salientia). Revista Brasileira de Biologia 26 (1): 29-37.

Bokermann, W.C.A. \& I. Sazima. 1973. Anfíbios da Serra do Cipó, Minas Gerais, Brasil. 1: Duas novas espécies de Hyla (Anura, Hylidae). Revista Brasileira de Biologia 33 (4): 457-472.

Brasileiro, C.A.; H.M. Oyamaguchi \& C.F.B. Haddad. 2007. A new island species of Scinax (Anura: Hylidae) from southeastern Brazil. Journal of Herpetology 41 (2): 271-275.

Caramaschi, U. \& G. Kisteumacher. 1989. Duas novas espécies de Ololygon Fitzinger, 1843, do Sudeste do Brasil (Amphibia, Anura, Hylidae). Boletim do Museu Nacional, (N.S.), Zoologia, 327: 1-15.

Cardoso, A.J. \& C.F.B. Haddad. 1982. Nova espécie de Hyla da Serra da Canastra (Amphibia, Anura, Hylidae). Revista Brasileira de Biologia 42 (3): 499-503.

Carvalho-e-Silva, S.P. \& O.L. Peixoto. 1991. Duas novas espécies de Ololygon para os Estados do Rio de Janeiro e Espírito Santo (Amphibia, Anura, Hylidae). Revista Brasileira de Biologia 51 (1): 263-270.
Cei, J.M. 1980. Amphibians of Argentina. Monitore Zoologico Italiano (N.S.), Monografia, 2: 1-609.

Cruz, C.A.G. \& O.L. Peixoto. 1983 Uma nova espécie de Hyla do Estado do Espírito Santo, Brasil (Amphibia, Anura, Hylidae). Revista Brasileira de Biologia 42 (4): 721-724.

Drummond, L.O.; D. BaÊTA \& M.R.S. Pires. 2007. A new species of Scinax (Anura, Hylidae) of the $S$. ruber clade from Minas Gerais, Brazil. Zootaxa 1612: 45-53.

Duellman, W.E. 2001. Hylid Frogs of Middle America. Lawrence, The Society for the Study of Amphibians and Reptiles, 1158p.

Faivovich, J. 2005. A new species of Scinax (Anura: Hylidae) from Misiones, Argentina. Herpetologica 61 (1): 69-77.

Faivovich, J.; C.F.B. Haddad; P.C.A. Garcia; D.R. Frost; J.A. Campbell \& W.C. Wheeler. 2005. Systematic review of the frog family Hylidae, with special reference to Hylinae: phylogenetic analysis and taxonomic revision. Bulletin of the American Museum of Natural History 294: 1-240.

Frost, D. R. 2010. Amphibian Species of the World: an Online Reference. Version 5.4 (8 April, 2010). Electronic Database accessible at http://research.amnh.org/vz/herpetology/ amphibia [Accessed: 11.X.2010].

Haddad, C.F.B. \& J.P. Pombal JR. 1987. Hyla hiemalis, nova espécie do grupo rizibilis do Estado de São Paulo (Amphibia, Anura, Hylidae). Revista Brasileira de Biologia 47 (1/2): 127-132.

Heyer, W.R. 1980. The calls and taxonomic positions of Hyla giesleri and Ololygon opalina. Proceedings of the Biological Society of Washington 98 (3): 657-671.

Heyer, W.R.; A.S. Rand; C.A.G. Cruz; O.L. Peixoto \& C.E. Nelson. 1990. Frogs of Boracéia. Arquivos de Zoologia 31 (4): 237 410.

Lima, L.P.; R.P. Bastos \& A.A. GiaretTA. 2005. A new Scinax Wagler, 1830 of the S. rostratus group from Central Brazil (Amphibia, Anura, Hylidae). Arquivos do Museu Nacional 62: 505-512.

Lourenço, A.C.C.; L.B. Nascimento \& M.R.S. Pires. 2009. A new species of the Scinax catharinae species group (Anura: Hylidae) from Minas Gerais, southeastern Brazil, Herpetologica 65 (4): 468-479.

Lutz, B. 1973. Brazilian Species of Hyla. Austin, University of Texas Press, 260p.

Myers, C.W. \& W.E. Duellman. 1982. A new species of Hyla from Cerro Colorado, and other tree frog records and geographical notes from western Panama. American Museum Novitates 2752: 1-25.

Oliveira-Filho, A.T. \& J.A. Ratter. 2002. Vegetation physiognomies and woody flora of the Cerrado Biome, p. 91-120. In: OliverRA, P.S. \& R.J. MARQUIS (Eds.). The Cerrados of Brazil: Ecology and Natural History of a Neotropical Savanna. New York, Columbia University Press, 398p.

Peixoto, O.L. \& P. Weygoldt. 1987. Notes on Ololygon heyeri Weygoldt 1986 from Espírito Santo, Brazil (Amphibia: Salientia: Hylidae). Senckenbergiana Biologica 68 (1/3): 1-9. 
Pombal JR, J.P. \& R.P.Bastos. 1996. Nova espécie de Scinax Wagler, 1830 do Brasil Central (Amphibia, Anura, Hylidae). Boletim do Museu Nacional (N.S.) Zoologia 371: 1-11.

Pombal JR, J.P.; R.P.Bastos \& C.F.B. Haddad. 1995. Vocalizações de algumas espécies do gênero Scinax (Anura, Hylidae) do sudeste do Brasil e comentários taxonômicos. Naturalia 20: 213-225.

Pombal Jr, J.P \& M. Gordo. 1991. Duas novas espécies de Hyla da Floresta Atlântica no Estado de São Paulo (Amphibia, Anura). Memórias do Instituto Butantan 53(1): 135-144.

Pimenta, B.V.S.; J. Faivovich \& J.P. Pombal JR. 2007. On the identity of Hyla strigilata Spix, 1824 (Anura: Hylidae): redescription and neotype designation for a "ghost" taxon. Zootaxa 1441: 35-49.

Pugliese, A.; D. Baêta, \& J.P. Pombal Jr. 2009. A new species of Scinax (Anura: Hylidae) from rocky montane fields in Southeastern and Central Brazil. Zootaxa 2269: 53-64.

Pugliese, A.; J.P. Pombal Jr \& I. Sazima, I. 2004. A new species of Scinax (Anura: Hylidae) from rocky montane fields of Serra do Cipó, Southeastern Brazil. Zootaxa 688: 1-15.

SaVage, J.M. \& W.R. Heyer. 1967. Variation and distribution in the tree-frog genus Phyllomedusa in Costa Rica, Central America. Beitraege zur Neotropischen Fauna 5: 11131.

Appendix 1. Addional examined specimens.

Scinax agilis: BrazIL, Bahia: Belmonte MNRJ 46853-54; Espírito Santo: Setiba MNRJ 43094-95. Scinax albicans: BraZIL, Rio de Janeiro: Duque de Caxias MNRJ 53670-87; Teresópolis MNRJ 53940-47. Scinax argyreornatus: BrazIL, Bahia: Canavieiras MNRJ 4030308; Espírito Santo: Santa Teresa MNRJ 28360-72; Sooretama MNRJ 42910-17; Rio de Janeiro: Angra dos Reis MNRJ 49656; Itaguaí MNRJ 32036-42. Scinax ariadne: São Paulo: São José do Barreiro, Serra da Bocaina MNRJ 4051 (paratype). Scinax aromothyella: Argentina, Misiones, Departamento de Guarany, San Vicente MNRJ 56445 (paratype). Scinax berthae: Argentina: Buenos Aires MNRJ 3590 (paratype); Brazil, Rio Grande do Sul: Santa Maria MNRJ 39897; São Paulo, Botucatu MNRJ 40581. Scinax canastrensis: BrazIL, Minas Gerais: São Roque de Minas MNRJ 4147 (holotype), MNRJ 4148 (paratype). Scinax carnevallii: BrazIL, Minas Gerais: Caratinga MNRJ 4201-09 (paratypes); Marliéria MNRJ 4182 (holotype), MNRJ 4183-85, 4187-200 (paratypes). Scinax brieni: Brazil, São Paulo: Paranapiacaba AL-MN 2592-94; MNRJ 54428-29. Scinax carnevallii: BrazIL, Minas Gerais: Caratinga MNRJ 4201-09 (paratypes); Marliéria MNRJ 4182 (holotype), MNRJ 4183-84 (paratypes), MNRJ 4185 (paratype). Scinax centralis: BrazIL, Goiás: Silvânia MNRJ 17465 (holotype) 17466-75 (paratypes). Scinax flavoguttatus: Brasil: Rio de Janeiro: Duque de Caxias MNRJ 53688-03; Teresópolis MNRJ 53950-58; São Paulo, Bananal, Serra da Bocaina MNRJ 23404-07. Scinax jureia: Brazil, São Paulo: Iguape MNRJ 14202-03 (paratypes). Scinax kautskyi: BRAzIL, Espírito Santo: Aracruz MNRJ 39785-98. Scinax hiemalis: Brazil, São Paulo: Botucatu MNRJ 23447-52, MNRJ 40008-09. Scinax humilis: BrazIL, Rio de Janeiro: Cachoeirra de Macacu MNRJ 40082-95; Duque de Caxias MNRJ 2248 (lectoptype), MNRJ 1478 (paralectotype), 53715-17; Rio de Janeiro MNRJ 40178-81. Scinax littoralis: BrazIL, São Paulo: Iguape MNRJ 46993. Scinax longilineus: BrazIL, Minas Gerais: Belo Horizonte MNRJ 16003-07, 30966-69; Poços Caldas MNRJ 4060 (holotype), MNRJ 44618. Scinax luizotavioi: BrazIL, Minas Gerais: Lima Duarte 36552-57; São Gonçalo do Rio Abaixo MNRJ 4473-4508 (paratypes); Santa Bárbara, Caraça MNRJ 4210 (holotype), 4211-15 (paratypes), 49684-88. Scinax machadoi: BRAzIL, Minas Gerais: Jaboticatubas MNRJ 17476-77 (paratypes), MNRJ 39696. Scinax obriangulatus: BrazIL, Minas Gerais: Alto Itatiaia MNRJ 3707, 14675-81, 54404-07, 54408, 54409-12, 54413, 54414-16. Scinax trapicheiroi: BRAzIL, Rio de Janeiro: Rio de Janeiro MNRJ 3623-25 (paralectotypes), MNRJ 27356-58, MNRJ 34883-84, MNRJ 47172-73. Scinax strigilatus: BRAzIL, Bahia: Belmonte MNRJ 38099; Ibirapiranga MNRJ 38098 (neotype); Jussari MNRJ 44946, 44948-49. Scinax ranki: BrazıL, Minas Gerais: Poços de Caldas MNRJ 49657. Scinax rizibilis: BraziL, São Paulo: Paranapiacaba MNRJ 4046, 14216, MNRJ40560-66; Ribeirão Branco MNRJ 18224-25; Ribeirão Grande MNRJ 28131-52; Santa Catarina: São Bento do Sul MNRJ 3629-30, 36349 (syntypes of Hyla mirim). Scinax tripui: BraziL, Minas Gerais: Ouro Preto MNRJ 42890 (holotype), 48762-67 (paratypes), 48743-45 (paratypes).

Submitted: 05.X.2009; Accepted: 19.IX.2010.

Editorial responsibility: Ana Lúcia da C. Prudente 